\title{
Small Slovene Firms and Strategic Information Technology Usage*
}

\author{
Dušan Lesjak ${ }^{* *}$
}

The article describes a study, which tries to identify the degree to which information technology is used strategically in Slovene small firms. Slovenia is interesting from small business perspective, because from 1990, when the transformation of its economy started, the number of small business has increased almost 6 times (from almost 6,500 to nearly 35,000 in 1998). In the paper the research model, hypothesis, methods and the research sample are explained, together with the results and discussion.

In dieser Arbeit wird eine Studie ausgewertet, welche das Ausmaß der strategischen Verwendung von Informationstechnologien in kleinen slowenischen Unternehmen thematisiert. Slowenien ist insofern interessant aus der Perspektive der kleinen Unternehmen, als sich dort seit 1990, dem Jahr, in dem die Transformation der Ökonomie einsetzte, die Zahl der kleinen Unternehmen beinahe versechsfacht hat (von fast 6500 auf beinahe $35000 \mathrm{im}$ Jahr 1998). Im vorliegenden Artikel wird das Forschungsmodell, die Hypothesen, Methoden und Beispiele genauso thematisiert wie die Forschungsergebnisse und ihre Implikationen.

\footnotetext{
* manuscript received: 26.11.1999, accepted: 23.1.2000;

** Lesjak Dušan, 1957, associate professor, Faculty of Business and Economics, University of Maribor, Department of Business Informatics, Chair of Business Informatics Institute; Main research topics: Strategic information technology usage in companies, Evaluation of information technology usage in companies, Strategic planning and developing of information systems
} 


\section{Introduction}

\subsection{General background}

Most information systems texts and a large volume of popular and scholarly literature suggest that information technology (IT) is playing an increasingly critical role in the design and implementation of organisational strategy. IT has been described as facilitating the competitiveness, organisational transformation, increasing market share, and heightening customer service because it provides information and serves as a communication channel among various participants in such a way that may alter the basis for industrial competition (Bhide 1994), (Peppard 1993), (Porter/ Miller 1985).

Indeed, case studies support the idea that IT helps firms in developing and implementing strategy, and that it yields direct economic benefit (Baura et al. 1995), (Taylor/ Todd 1995). Year after year, increasingly affordable computers and other IT tools are produced to assist in the design and evaluation of strategy (Bergeron et al. 1998).

If this is the case, why then do surveys in small and medium size enterprises suggest that two-thirds of the firms or fewer do not use IT strategically (Taylor/ Todd 1995), (Lesjak 1993). Apparently, it is more common for firms to design and implement strategy without the aid of the IT applications they have, and instead, to relegate IT to perform routine internal operations (Moreton 1995), (Langley/ Traux 1994).

The purpose of this study is to identify the degree to which IT is used strategically in Slovene small firms, and to investigate the possible reasons and consequences for patterns of usage. As small firms struggle for positions of leadership in their respective industries, IT offers a possible advantage for the growing Slovene small firms. The question is: Is it being leveraged to that end?

\subsection{Slovenia's Economic Transformation}

Although small, Slovenia leads many Central and Eastern European (CEE) transitional economies in economic growth and productivity. Slovenia's small firms have played an important role in this transition. By transforming its economy Slovenia has established a fertile basis for small business growth and development. The number of Slovene small firms has increased six fold since 1990, when the transformation of Slovenia's economy began. In 1998, 35,205 small firms represented almost $94 \%$ of all companies (1,478 midsize and 869 large companies).(Ministry of Small... 1999) 
Figure 1: Number of Small Firms in Slovenia

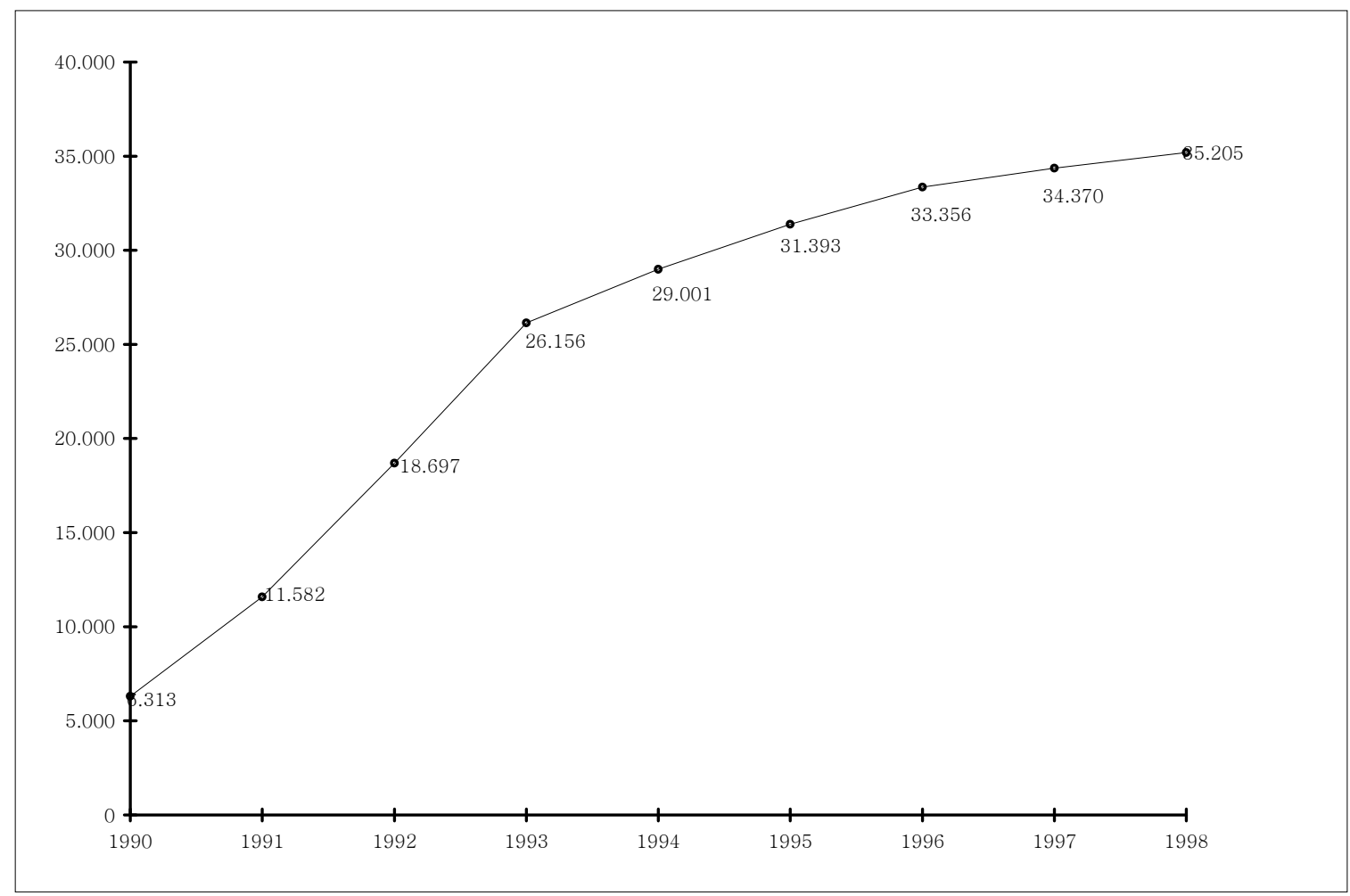

If we compare the percentage of small businesses in Slovenia to that in the USA and European Union we come across similar patterns. But if we compare the portion of total employment in small business in Slovenia to that in the USA and Europe, there is a rather big difference. For example, in the USA, small business represents $97 \%$ of all businesses and $57 \%$ of the employment, in Europe: $98 \%$ (in 1997 98.92\%) of all business and 46\% of employment (Heikkila et al. 1991). Although there is a fair amount of variability in the employment share of small firms in Western Europe (ranging from Spain's high of $81.1 \%$ down to Belgium's low of $56.2 \%$ (Kagar/ Blumenthal 1994) - they are considerably higher than Slovenia's 24\% (Rue/ Ibrahim 1995). The sectors represented by small firms differ as well. For example, although only 10\% of Western Europe's new small firms have been in the area of manufacturing and construction, these sectors constitute $42 \%$ of new small firms in Slovenia (Chamber of Commerce... 1998).

Structural differences between Slovenia's small firms sectors and those of Western Europe, as well as year-to-year indicators, suggest that transition is still taking place among Slovene small firms. 


\section{Information Technology and Strategy}

\subsection{Defining Strategic IT applications}

A strategic IT usage is the use of information and IT which can help develop, define and redefine, test, and, in some cases, implement strategy and develop a given product or specific business function or activity within which IT usage has a strategic impact. As such, we are interested in the role that IT can play in:

- supporting the on-going evolution of strategy on the one hand and

- enhancing firm's competitiveness and co-operation on the other hand.

The line between strategic and non-strategic applications is a fine one. Academic researchers typically differentiate between strategy and implementation, although directors and CEOs may make this distinction much less often (Gopinath/ Hoffman 1995). Additionally, it is sometimes difficult to identify whether a given IT application is strategic or not. Wiseman (1994), for example, suggests that strategic IT is largely determined by each firm's environment, its basis for competition, and strategy. Using IT to closely monitor inventory levels might be strategic in a firm, which competes on the basis of low costs, but not in a firm, which competes through innovation. Thus, particular IT use has to be paired with firm strategy to identify whether the usage is strategic or not.

The impact of various IT applications, however, may help differentiate strategic IT usage. Moreton (1995) emphasises three outcomes from IT applications as strategic: IT is strategic when it enhances an organisation's ability to change and respond to environmental shift; facilitates movements toward various strategic outcomes such as customer satisfaction, streamlined business processes, and decentralisation, and when it reduces the mundane aspects of jobs, allowing a reorganisation of work, which encourages more learning and innovation. Each of these impacts suggest that strategic IT applications are not stand-alone functions, but well integrated with strategy, people, and operations (Blennerhassett/ Galvin 1993).

\subsection{Gaps Between Strategy, Practice, and Effectiveness}

There is a sizeable body of literature examining IT diffusion (Moore/ Benbasat 1991), the growth of IT in firms (Covin et al. 1994), and the increasing proficiency (literacy) of IT users (Rainer/ Harrison 1995). None of this addresses the strategic use of IT, however, which is where much of the theoretic potency in IT applications lies.

A number of reasons can be suggested as the reason, why IT might or might not be used strategically in a firm. OECD (1989) concludes that information system fails, when it is not implemented with the users and organisational setting in mind at the time of implementation. Parker and Swatman (1995), highlight several reasons why this may be the case: 
- The lack of awareness of IT capabilities,

- The time required to become acquainted with IT products and capabilities,

- The lack of vision regarding IT's cost savings (or revenue enhancement),

- The general absence of strategic perspectives in some SMEs.

Although there is evidence on both sides, some research has shown that attempts to manage strategically yielded few advantages in firm performance. Slight but not substantial association between comprehensive historical financial reporting/use of financial ratio analysis and the rate of growth/firm performance has been reported (Thomas/ Evanson 1987), (McMahon/ Davies 1994). There's no significant difference between formal and informal planning in terms of problems which arise in the planning process or in the achievement of planning goals in a sample of US small banks (Kagar/ Blumenthal 1994). Others have found that formal planning makes a difference (Lussire 1995).

\section{3 “Defining” Strategic IT Usage}

Based on existing literature, a theoretical model and accompanying hypotheses can be generated regarding possible influences on the strategic IT usage in small firms (see Figure 2). Previous studies suggest that there are at least two influences, which may impact the degree to which IT is used strategically:

- firm characteristics and

- firm strategy.

Figure 2: Model of Strategic IT Usage

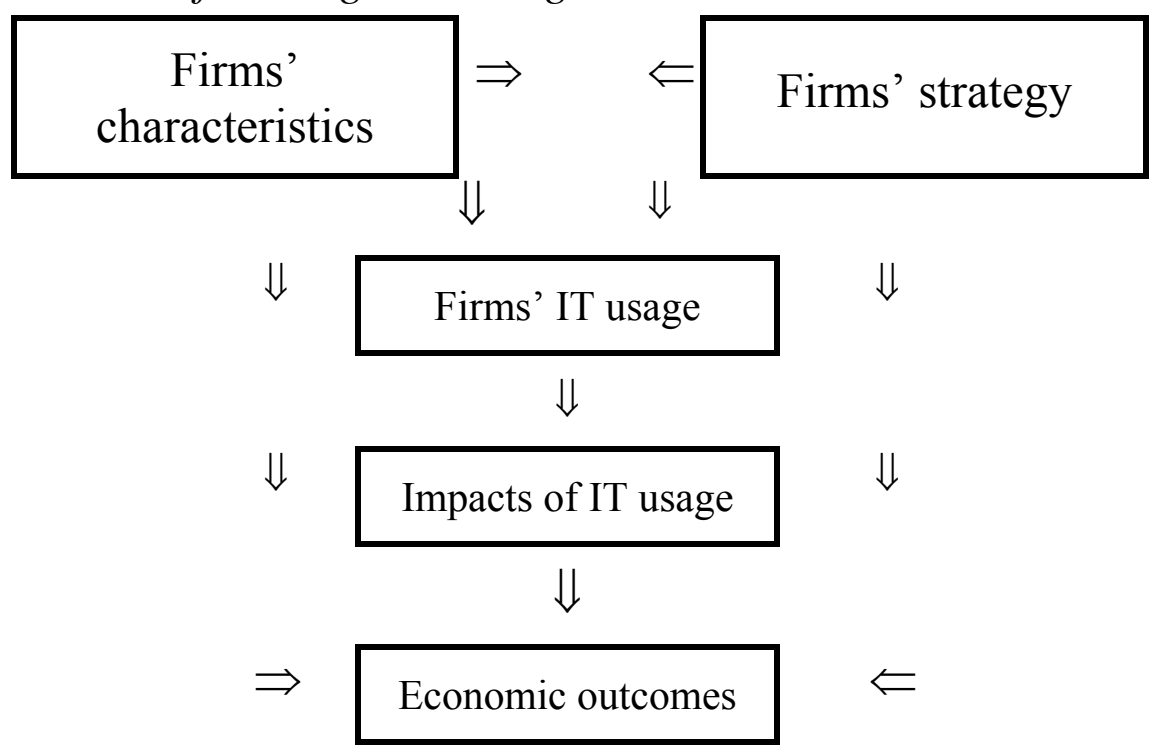

Some latest research (Bergeron et al. 1998) hasn't confirmed our presumption that a firm's environment as well has as an important influence on strategic IT usage. 
Firms' characteristics. Previous research indicates that small firms do not as much or as formal strategic planning as do large firms (Bhide 1994), (Rue/ Ibrahim 1995). This may be due to the fact that small firm employees tend to be generalists rather than specialist (Matthews/ Scott 1995), or because small firms are not always growth-oriented and often have a variety of goals, which impact the desirability of planning (Bhide 1994). As firms become older, they tend to grow in size. Thus, we see the firm's size and age, as being positively associated with strategic IT usage. We hypothesise that:

H1: The older the firm, the more frequently IT applications will be strategic.

Strategy. Research consistently shows that entrepreneurs and managers of SMEs vary in the competitive strategies they employ (Covin et al. 1994), (Kagar/ Blumenthal 1994). The choice of strategy is influenced in part by the degree to which the firm is oriented towards growth, and the degree to which SME managers are aggressively pro-active and entrepreneurial rather than reactive. The specific strategy employed will give priority to certain IT applications over others (Wiseman 1994) (sales IT applications, where customer service is important; purchasing IT applications, where resources are shared across divisions, etc.).

H2: Firms will tend to use IT strategically, where applications match the core elements of their strategies.

IT Usage. There is some evidence that the more IT is spread across various business areas or functions and the more it is involved in different areas, the more familiar employees and management will become with possible IT applications, and the more likely they will use IT strategically. Thus, we hypothesise that:

H3: The breadth of IT usage across various business areas will positively correlate with strategic IT applications.

Impacts of IT usage. The impacts of IT usage will be classified into strategic and non-strategic ones, due to their contribution to enhancement of firm's competitiveness and co-operation. Impacts of IT usage will be matched with particular strategy types and again combinations of impacts will become our dependant variables.

Economic outcomes. Additionally, we ask respondents to indicate how important a set of financial measures is in their firm and the degrees of satisfaction with firm performance on these outcomes. We also ask respondents to evaluate their relative standing on financial outcomes when compared to their competitors. We will try to find relations between the strategic IT usage and firms' economic outputs. 


\section{Methods}

\subsection{Measures/Variables}

Strategy. Strategy was measured in two ways taken from: Covin et al. (1994) and Kim and Choi (1995).

IT Usage. IT strategic usage was measured in two ways: With a 6-item measure of IT applications within functional area are used by Cragg and King (1993); and, with a 3-item measure of the overall role of IT by Grover (1993).

Impacts of IT Usage. This was measured by 16-item measure designed for the present study.

Economic Outcomes. This was measured by 11 -item measure which involve traditional economic criteria such as sales, revenue, profit, ROI, etc.

\subsection{Research Sample}

In this study, the criteria for defining a small business were adopted from the Agency for Payment System of Slovenia (1998). A small business is one that satisfied at least two of the following points. It has:

- 50 or fewer employees

- fixed assets should be of 500.000 Euro or less, and

- annual sales of 1 million Euro or less.

In our sample we employed two additional criteria. We selected firms with:

- an annual revenue of more than 100.000 Euro to exclude firms which probably cannot afford IT, and

- 10 or more employees to exclude micro firms.

The names and the addresses of small businesses that fulfil the above criteria were obtained from the state Agency for Payment System (APS) of Slovenia. Non-profit organisations, publicly owned businesses, and wholly-owned subsidiaries of large businesses were excluded from the survey sample, leaving a sample of 974 businesses or $2.84 \%$ of all small firms in Slovenia.

\subsection{Procedures}

The study was conducted in Slovenia in two phases: A pilot study and the questionnaire survey. A pilot version of the "Small Business IT Usage Questionnaire" was compiled in Slovene and pre-tested with MBA students. Additionally, students taking a small business management course pre-tested

Table 1: Characteristics of the Sample

\begin{tabular}{|l|l|l|l|}
\hline Characteristic & Choices & Frequency & Percent \\
\hline
\end{tabular}




\begin{tabular}{|l|c|c|c|}
\hline Sector & Manufacturing & 68 & 46.3 \\
& Trade & 42 & 28.6 \\
& Business Services & 26 & 17.6 \\
& Construction & 11 & 7.5 \\
\hline Years in business & $>7$ years & 25 & 17.0 \\
& $<7$ & 122 & 83.0 \\
\hline Operating at a profit or loss & Profit & 127 & 86.4 \\
& Breakeven & 1 & .7 \\
\hline Number of full-time equivalent & Loss & 19 & 12.9 \\
employees & $10-20$ & 80 & 54.8 \\
& $21-30$ & 22 & 15.1 \\
& $31-40$ & 16 & 10.9 \\
& $41-50$ & 13 & 8.9 \\
\hline Profit-loss/employees & $51-$ & 16 & 10.3 \\
\hline Employees, who are IT users & $-5,000$ & 17 & 11.6 \\
& $5,001-10,000$ & 43 & 29.2 \\
& $10,001-20,000$ & 49 & 33.3 \\
& $20,001-30,000$ & 21 & 14.3 \\
& $30,001-$ & 17 & 11.6 \\
\hline Computer usage in the firm & $>8$ years & 44 & 29.9 \\
& $6-7$ & 27 & 18.4 \\
& $41 \%-85 \%$ & 33 & 22.4 \\
& $11 \%-40 \%$ & 38 & 25.9 \\
& $0 \%-10 \%$ & 36 & 24.5 \\
\hline & $15 \%-100 \%$ & 35 & 23.8 \\
& $6 \%-14 \%$ & 35 & 23.8 \\
& $1 \%-5 \%$ & 46 & 31.3 \\
& $0 \%$ & 31 & 21.1 \\
\hline
\end{tabular}

the questionnaire on 10 small businesses randomly chosen from the small business database. Based on feedback from both sources, the questionnaire was refined or the next phase of the study. (Responses from these pilot study businesses were not included in the final sample). 
In the questionnaire survey phase, the questionnaire was mailed to the 974 small businesses in the survey sample. The questionnaire was completed by the person who is most closely responsible for IS within the firm. In small businesses that is usually the top manager or the owner. Quantitative data on the organisational characteristics (e.g. business sector, number of employees, annual sales, profit/loss, etc.) of the small businesses were obtained from the APS of Slovenia. All businesses are requested annually to file a report with the APS.

Of the sent surveys, 161 were returned, giving a response rate of $16.5 \%$. Responses from 14 businesses were discarded because they had incomplete data, resulting in a final sample of 147 usable questionnaires.

To insure that the respondents were similar in characteristics to the population, these final 147 firms were compared to the 974 in terms of the number of employees, income, and income per employee (Data on all firms were obtained from the APS.). T-tests showed no significant differences on any of these measures (income: $\mathrm{t}=0.65 ; p=.52$; employees: $\mathrm{t}=0.30 ; p=.76$; income per employee: $\mathrm{t}=0.72 ; p=.47)$.

\section{Results and Discussion}

\subsection{Sample}

Table 1 presents the sample characteristics. The responding small businesses are from manufacturing, trade (e.g., import-export), business services (e.g., consulting), and construction sectors.

On average, small businesses in the sample had 29.3 employees and mean annual sales per employee of 101,922 Euro. The average firm had 5.8 years of computer experience, and about $50 \%$ of their employees computer literate.

\subsection{Instrument Validation (Assessing Reliability)}

For each composite variable, the reliability (internal consistency) was assessed by calculating Cronbach's alpha coefficient as suggested in (Carmines/ Zeller 1981). Table 2 also presents the results of reliability testing.

The reliability coefficients were higher than 0.7 except strategy-low cost (alpha $=0.67$ ), suggesting that the research variables are satisfactorily reliable (Nunnally 1978). The item-total correlation coefficients of items of research

Table 2: Reliability and Factor Analysis of Variables ( ${ }^{a}$ Cronbach Alpha (Standard), ${ }^{v}$ Variance explained)

\begin{tabular}{|l|c|c|}
\hline Items & $\begin{array}{l}\text { Item-total } \\
\text { correlation }\end{array}$ & $\begin{array}{l}\text { Factor } \\
\text { loading }\end{array}$ \\
\hline Differentiation Strategy: & $.72^{\mathrm{a}}$ & $55.0 \%{ }^{\mathrm{v}}$ \\
\hline
\end{tabular}




\begin{tabular}{|l|c|c|} 
Emphasizing product and/or service & .43 & .67 \\
quality & .68 & .86 \\
Investing in research and development & .48 & .72 \\
Emphasizing education and training of & .48 & .70 \\
employees & & \\
Developing new products or services &. $\mathbf{6 7}^{\mathbf{a}}$ & $\mathbf{5 0 . 9}^{\mathbf{v}}$ \\
\hline Low Cost Strategy: & .37 & .62 \\
\hline Being a low-cost producer & .60 & .87 \\
Automating functions as much as possible & .44 & .76 \\
Maximising efficiency of business & .35 & .57 \\
activities & & \\
Maintaining very low-level inventories & $.75^{\mathrm{a}}$ & $\mathbf{3 7 . 3 \%}$ \\
\hline Firm IT Usage: & .43 & .61 \\
\hline Research and development & .58 & .72 \\
Purchasing/Procurement & .62 & .76 \\
Production & .35 & .50 \\
Marketing and Sales & .38 & .55 \\
Inventory (warehousing) & .50 & .65 \\
Transport & .56 & .63 \\
Personnel/Humane Resources & .27 & .39 \\
Finance and Accounting & & \\
\hline
\end{tabular}


Table 2 continued

\begin{tabular}{|l|c|c|}
\hline Impact of IT Usage: & $\mathbf{. 9 1}^{\mathrm{a}}$ & $\mathbf{5 2 . 2 \mathbf { \% } ^ { \mathrm { v } }}$ \\
\hline The quality of products and/or services & .68 & .75 \\
Quality of producing products/services & .64 & .71 \\
Finding new business opportunities & .65 & .72 \\
Finding new markets & .64 & .71 \\
Business process redesign & .67 & .74 \\
Firm's capabilities to adjust to changes & .75 & .81 \\
Introducing new products and/or services & .68 & .75 \\
Introducing new production and business & .71 & .77 \\
technology & .62 & .69 \\
Customer satisfaction & .57 & .64 \\
Employee satisfaction & .56 & .63 \\
Business risk & & \\
\hline Financial performance: & $.91^{\mathrm{a}}$ & $\mathbf{5 4 . 6 \%}{ }^{\mathrm{v}}$ \\
\hline Annual sales & .47 & .56 \\
Annual sales growth & .64 & .71 \\
Revenue & .66 & .73 \\
Revenue growth & .73 & .78 \\
Profit & .74 & .82 \\
Profit growth & .80 & .86 \\
Profitability & .76 & .82 \\
Return on investment (ROI) & .71 & .78 \\
Solvency & .58 & .62 \\
Ability to fund business growth from & .73 & .77 \\
profits & & \\
Overall firm performance & & \\
\hline
\end{tabular}

variables were also high, indicating reasonable reliability of the research variables.

To assess whether the item of the variables constituted different scales of variables, a principal component factor analysis was performed (Carmines/ Zeller 1981). Table 2 indicates that almost all the factor loadings are greater than 
the recommended cut-off point of 0.5 (except the item Finance and Accounting in the Firm IT Usage column: 0.39) and all the items loaded on their hypothesised factors (Nunnally 1978). Hence, we are confident that construct validity was not violated. These results also provided confidence to combine various items under different variables into one construct. Since we weren't satisfied with the percent of the explained variance of the first component for the research variable "Firm IT usage" (37.3\%) and factor analysis revealed more than one underlying dimension for a construct, the factor was further examined. An eigenvalue of 0.9 or above was used as a criterion to estimate the number of factors underlying the construct. Because the construct had 3 interpretable dimensions (which altogether explain $66.6 \%$ of the variance), reliability was computed for each dimension. (Table 3).

Table 3: Total variance explained for the variable "Firm IT usage"

\begin{tabular}{|c|c|c|c|}
\hline \multirow[b]{2}{*}{ Components } & \multicolumn{3}{|c|}{ Initial Eigenvalues } \\
\hline & Total & $\begin{array}{l}\text { Percent of } \\
\text { Variance }\end{array}$ & $\begin{array}{l}\text { Cumulative } \\
\text { Percent }\end{array}$ \\
\hline $\mathrm{C} 1$ & 2.98 & 37.29 & 37.29 \\
\hline $\mathrm{C} 2$ & 1.41 & 17.58 & 54.88 \\
\hline C3 & .94 & 11.71 & 66.59 \\
\hline$\ldots$ & $\ldots$ & $\ldots$ & $\ldots$ \\
\hline
\end{tabular}

For the first 3 components we performed Principle Component Analysis to identify any related forms of IT usage (Varimax with Kaiser Normalization rotation method). Table 4 shows that components represent different industries:

- C1 represents manufacturing firms because research/development and production functions have high coefficients,

- C2 represents trade, because marketing/sales and transportation functions have high coefficients, and

- C3 represents business services because personnel/human resources and finance/accounting have high coefficients in the contrast with marketing/sales.

To realise the influence among the introduced measures/components of strategic IT usage, (i.e., introduced components for the following variables: Firm Strategy, Firm IT Usage, Impact of IT Usage, and Financial Performance), Pearson correlations was used. The results are shown in Table 5. 
Table 4:Rotated Component Matrix

\begin{tabular}{|l|c|c|c|}
\hline Firm IT Usage: & Manufacturing & Trade & $\begin{array}{c}\text { Business } \\
\text { service }\end{array}$ \\
\hline Research and development & .92 & & \\
Purchasing/Procurement & .35 & .35 & .29 \\
Production & .72 & .32 & -.10 \\
Marketing and Sales & .20 & .85 & .21 \\
Inventory (warehousing) & .28 & .80 & .22 \\
Transport & & .11 & .81 \\
Personnel/Human Resources & & & .85 \\
Finance and Accounting & & & \\
\hline
\end{tabular}

Table 5: Descriptive Statistics and Significant Correlations

\begin{tabular}{|l|c|c|c|c|c|c|c|c|c|}
\hline Variable & Mean & s.d. & 1 & 2 & 3 & 4 & 5 & 6 & 7 \\
\hline $\begin{array}{l}\text { 1. Differentiation } \\
\text { strategy }\end{array}$ & 5.28 & 1.07 & & & & & & & \\
\hline $\begin{array}{l}\text { 2. Low cost } \\
\text { strategy }\end{array}$ & 5.49 & 1.02 & $.39^{* *}$ & & & & & & \\
\hline $\begin{array}{l}\text { 3. IT usage in } \\
\text { manufacturing }\end{array}$ & 4.78 & 1.63 & & $.18^{*}$ & & & & & \\
\hline $\begin{array}{l}\text { 4. IT usage in } \\
\text { trade }\end{array}$ & 5.28 & 1.45 & & $.36^{* *}$ & & & & & \\
\hline $\begin{array}{l}\text { 5. IT usage in } \\
\text { business services }\end{array}$ & 5.13 & 1.69 & & & & & & & \\
\hline $\begin{array}{l}\text { 6. Impact of IT } \\
\text { usage }\end{array}$ & 5.12 & .87 & $.26^{* *}$ & $.24^{* *}$ & $.28^{* *}$ & $.30^{* *}$ & $.37^{* *}$ & & \\
\hline $\begin{array}{l}\text { 7. Financial } \\
\text { Performance }\end{array}$ & 5.00 & .79 & $.31^{* *}$ & $.23^{*}$ & & $.19^{*}$ & & $.18^{*}$ & \\
\hline
\end{tabular}

${ }^{* *} p \geq .01$ (2-tailed), ${ }^{*} p \geq .05$ (2-tailed)

Table 5 shows the following interesting significant correlations:

- Low cost strategy correlates with the IT usage among manufacturing and especially trade firms, what is actually not surprising. Unfortunately there is no significant correlation among firms following differentiation strategy (such as business services firms) and IT usage. 
- Both strategies correlates with the financial performance of the firms, but the questions is whether the IT usage and impacts of IT usage make any contribution to that performance?

- IT usage in firms from all 3 industries significantly correlates with the impacts of IT usage, what is somehow anticipated, because if a firm uses IT heavily, than impacts of that kind of usage are expected.

- Interestingly, there is a significant correlation only among impacts of IT usage and the financial performance of the firms from trade industry.

- Interestingly again, there exist a weak but significant correlation between impacts of IT usage and financial performance of firms. So, we could say that there is a certain influence of IT usage on financial performance of firm.

\section{Conclusion}

Overall, general idea that IT is used strategically:

- if IT applications support business strategy

- in terms of IT usage across various business areas

- what should have a certain positive impacts of IT usage on firms and

- what altogether should reflect in financial performance of firms

was at least partially supported by the research.

The results suggest that Slovene small firms indeed are using some applications of IT strategically. Especially manufacturing and trade firms which are following low costs strategy. That is proved not only by various impacts of IT usage on firms but as well as by positive influence of IT usage and its impacts on firms' financial performance.

Weaknesses of the present study include the following: We assumed that the common utilisation of IT applications in economic sectors was an indicator of areas of strategic importance. There may be some multicollinearity present between the variables, however. Additionally, environmental variables might be tested in further research, as might the reasons why small firms' managers/owners do and don't utilise IT strategically.

\section{Acknowledgement}

Appreciation is expressed to the MBA students, who contributed many useful comments about a questionnaire and to the students in Small Business Management university program, as well as to the students from Esbjerg Business Academy, Denmark who both tested the questionnaire in small firms in their country. 


\section{References}

Agency for Payment System of Slovenia (1998): Bulletin on the Business Results within the Economy of Slovenia.

Bergeron, F./ Raymond, L./ Gladu M./ Leclerc, C. (1998): The Contribution of IT to the Performance of SMEs: Alignment of Critical Dimensions. Baets, W.R.J. (editor) Proceedings of the $6^{\text {th }}$ European Conference on IS, France, Aix-en-Provence, I, pp 173-187.

Baura, A./ Kriebel, C. H./ Mukhopadhyay, T. (1995): Information Technologies and Business Value: An Analytic and Empirical Investigation, in: Information Systems Research, No. 6, pp 3-23.

Bhide, A. (1994): How Entrepreneurs Craft Strategies that Work, in: Harvard Business Review, March-April, pp 150-161.

Blennerhassett, L./ Galvin, E. (1993): The Strategic Dimension. In: Peppard, J. (ed.), I.T. Strategy for Business. London: Pitman Publishing, pp 26-52.

Carmines, E.G./ Zeller, R.A: (1981): Reliability and Validity Assessment, Beverly Hill, CA: Sage.

Chamber of Commerce and Industry of Slovenia (1998): Analysis of Business Results of Small Business in 1997.

Covin, J.G./ Slevin, D.P./ Shultz, R. L. (1994): Implementing Strategic Mission: Effective Strategic, Structural and Tactical Choices, in: Journal of Management Studies, 31, pp 481-504.

Cragg, P.B./ King, M. (1993): Small-Firm Computing: Motivators and Inhibitors, in: MIS Quarterly, March, pp 47-60

Gopinath, C./ Hoffman, R.C. (1995): The Relevance of Strategy Research: Practitioner and Academic Viewpoints, in: Journal of Management Studies, 32, pp 575-594.

Grover, V. (1993): An Empirically Derived Model for the Adoption of Customer-based Interorganizational Systems, in: Decision Sciences, 24(3), pp 603-640.

Heikkila, J./ Saarinen, T./ Assksjavri, M. (1991): Success of Software Packages in Small Business; an Exploratory Study, in: European Journal of Information Systems, 1, pp 159-167.

Kagar, J., Blumenthal, R.A. (1994): Successful Implementation of Strategic Decisions in Small Community Banks, in: Journal of Small Business Management, 32(2), pp 10-22.

Kim, Y., Choi, Y. (1995): Strategic Types and Performances of Small Firms in Korea, in: International Small Business Journal, 13(1), pp 13-25.

Langley, A./ Traux, J. (1994): A Process Study of New Technology Adoption in Smaller Manufacturing Firms, in: Journal of Management Studies, 31: pp 621-652.

Lesjak, D. (1993). Evaluating (current and future) impacts of information technology usage, in: Advances in management. Windsor (Ont.): The International Institute for Advanced Studies in Systems Research and Cybernetics, pp 143-148.

Lussire, R.N. (1995): An Nonfinancial Business Success Versus Failure Prediction Model for Young Firms, in: Journal of Small Business Management, 33(1), pp 8-20. 
Matthews, C.H./ Scott, S.G. (1995): Uncertainty and Planning in Small and Entrepreneurial Firms: An Empirical Assessment, in: Journal of Small Business Management, 33(4), pp 34-41.

McMahon, R.G.P./ Davies, L.G. (1994). Financial Reporting and Analysis Practice in Small Enterprises: Their Association with Growth Rate and Financial Performance, in: Journal of Small Business Management, 32(1), pp 9-17.

Ministry of Small Business and Turism. (1999): Small Business in Slovenia.

Moore, G.C., Benbasat, I. (1991): Development of an Instrument to Measure the Perceptions of Adopting an Information Technology Innovation, in: Information Systems Research, 2(3), pp 192-222.

Moreton, R. (1995): Transforming the Organization: The Contribution of the IS Function, in: Journal of Strategic Information Systems, No. 4, pp 149-163.

OECD (1989): New Technologies in the 1990s. OECD Observer, pp 155.

Nunnally, J.C. (1978): Psychometric Theory, McGraw-Hill, New York

Parker, C. M./ Swatman, P.M.C. (1995), Encouraging SME Acceptance of EDI: An Educational Approach, in: Clarke, R./ Gričar, J./ Novak, J. (eds.), Electronic Commerce for Trade Efficiency (Proceedings), Paper presented at the Eight International Conference of Electronic Data Interchange and Inter-Organisational Systems, Bled, Slovenia, June, pp 27-46.

Peppard, J. (1993): Using IS/IT to Gain Competitive Advantage, in: Peppard, J. (ed.), I.T. Strategy for Business. London: Pitman Publishing, pp 53-74.

Porter, M.E./ Miller, V.E. (1985): How Information Gives You a Competitive Advantage, in: Harvard Business Review, No. 4, pp 149-160.

Rainer, R.K.,Jr./ Harrison, A.W. (1995): Toward Development of the End User Computing Construct in a University Setting, in: Decision Sciences, 24(6), pp 1187-1201.

Rue, L.W./ Ibrahim, N.A. (1995): The Status of Planning in Smaller Family-Owned Business, in: Family Business Review, 9(1), pp 29-43.

Taylor, S./ Todd, P.A. (1995): Understanding Information Technology Usage: A Test of Competing Models, Information Systems Research, No. 6, pp 144-152.

Thomas, J./ Evanson, R.V. (1987): An Empirical Investigation of Association Between Financial Ratio Use and Small Business Success, Journal of Business Finance and Accounting, 14(4), pp 555-571.

Wiseman, C. (1994): Foreword, in: Ciborra, C., Jelassi, T. (eds.), Strategic Information Systems: A European Perspective. John Wiley \& Sons, Chichester, England, pp xiixiv. 


\section{Appendix}

\section{Information Technology Usage in Small Slovene Firms}

\section{An International University Research Questionnaire}

\section{Rank first 3 industries in which you earned your revenue in last period (3 years) :}

Comment: The reason why I named industries is because I know the research group of firms!

$\begin{array}{lll}\square \text { manufacturing } & \square \text { elect. gas and water ... } \\ \square \text { trade } & \square \text { transport, storage and } & \square \text { health and social work } \\ \square \text { real estate, bus, activities } & \text { communication } & \square \text { other comm. ... activities } \\ \square \text { construction } & \square \text { hotels and restaurants } & \square \text { other: }\end{array}$

2. What parts of your revenues come from sales: (in \%; sum is 100\%)

$\ldots$ _ in SLO _ $\%$ in ex YU countries _ _ $\quad$ \% in EU _ $\quad$ \% other:

3. How important are the following factors for your firm's business (circle one number on each row):

Making my product or service unique

Excelling in customer service

Focusing on a narrow, well-defined customer group

Being a low-price competitor

Being a low-cost producer

Emphasizing product and/or service quality

Automating functions as much as possible

Investing in research and development

Emphasizing education and training of employees

Developing new products/services

Emphasizing advertising and/or sales activities

Building the firm's and/or product/service image

Maintaining very low-level inventories

Other:

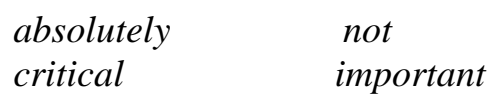




\section{To what degree do you agree with the statements about your firm's orientation? (mark one)}

$\square$ Increase sales and my customer base (willing to accept low profits in the short/medium term, if necessary)

Maintain my customer base and obtain moderate profits

Maximize profits and revenues in the short to medium term (willing to reduce customer base if necessary)

Prepare to sell or close my company or go bankrupt

$\square$ Other--None of the above (please specify):

5. To what degree do you agree with the following statements about your firm's practice? (mark one)

I manage on a day-to-day basis without a real plan or strategy

I make major business decisions only after considering the strategic implications of the decision

Without much forethought, I could easily describe my strategy to someone else

Most company employees could state our firm's business strategy

\section{Please indicate your firm's general practice with the following business activities):}

$\begin{array}{lll}\text { Somebody else } & \text { extensive use } & \text { without use of we do not do } \\ \text { is doing that } & \text { of computer } & \text { computer and that } \\ \text { for us } & \text { and IT tools } & \text { IT tools }\end{array}$

Research and Development:

(product development, development project management)

$\mathrm{x}$

$\begin{array}{lllllll}7 & 6 & 5 & 4 & 3 & 2 & 1\end{array}$

0

Purchasing/Procurement: (market research, purchase planning,

ordering...)

Production product/obtaining

services: (planning, production...

\begin{tabular}{|c|c|c|c|c|c|c|c|}
\hline $\mathrm{X}$ & 7 & 6 & 5 & 4 & 3 & 2 & 1 \\
\hline 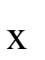 & 7 & 6 & 5 & 4 & 3 & 2 & 1 \\
\hline 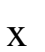 & 7 & 6 & 5 & 4 & 3 & 2 & 1 \\
\hline
\end{tabular}

inventory plan, stocks...)

X

$\mathrm{x}$

$\begin{array}{lllllll}7 & 6 & 5 & 4 & 3 & 2 & 1\end{array}$

planning, transport, Transport

capacities...) 
Personnel/Human Resources:

(forecasting labor demand,

$\mathrm{x}$

$\begin{array}{lllllll}7 & 6 & 5 & 4 & 3 & 2 & 1\end{array}$

0

calculation of wages/salaries...)

Finance and Accounting: (capital

and cash budgeting, invoicing,

$\mathrm{x}$

$\begin{array}{lllllll}7 & 6 & 5 & 4 & 3 & 2 & 1\end{array}$

0

bookkeeping...)

Office Administration:

$$
\begin{array}{lllllllll}
\mathrm{x} & 7 & 6 & 5 & 4 & 3 & 2 & 1 & 0
\end{array}
$$

Managerial (Decision) Support:

(DSS, EIS, ES...)

$\begin{array}{lllllllll}\mathrm{x} & 7 & 6 & 5 & 4 & 3 & 2 & 1 & 0\end{array}$

Communications in a firm and with its environment(such as Email, Internet, Intranet...)

$\begin{array}{llllllll}\mathrm{x} & 7 & 6 & 5 & 4 & 3 & 2 & 1\end{array}$

\section{Realistically, what do you think are the impacts of IT usage in your firm on:}

\section{in increasing...}

The quality of products and/or services

Quality of producing products/services

Finding new business opportunities

Finding new markets

Business process redesign

Firm's capabilities to adjust to changes

Introducing new products and/or services

Introducing new production and business technology

Employee satisfaction

Customer satisfaction

in decreasing...

Administrative costs

Business risk

Routine work

Number of employees

Production and/or service delivery costs

Production and/or service delivery time strong impact

no impact

$\begin{array}{lllllll}7 & 6 & 5 & 4 & 3 & 2 & 1 \\ 7 & 6 & 5 & 4 & 3 & 2 & 1 \\ 7 & 6 & 5 & 4 & 3 & 2 & 1 \\ 7 & 6 & 5 & 4 & 3 & 2 & 1 \\ 7 & 6 & 5 & 4 & 3 & 2 & 1 \\ 7 & 6 & 5 & 4 & 3 & 2 & 1 \\ 7 & 6 & 5 & 4 & 3 & 2 & 1 \\ 7 & 6 & 5 & 4 & 3 & 2 & 1 \\ 7 & 6 & 5 & 4 & 3 & 2 & 1 \\ 7 & 6 & 5 & 4 & 3 & 2 & 1\end{array}$

strong impact

no impact

$\begin{array}{lllllll}7 & 6 & 5 & 4 & 3 & 2 & 1 \\ 7 & 6 & 5 & 4 & 3 & 2 & 1 \\ 7 & 6 & 5 & 4 & 3 & 2 & 1 \\ 7 & 6 & 5 & 4 & 3 & 2 & 1\end{array}$

$\begin{array}{lllllll}7 & 6 & 5 & 4 & 3 & 2 & 1\end{array}$

$\begin{array}{lllllll}7 & 6 & 5 & 4 & 3 & 2 & 1\end{array}$ 
8. Please classify where you think your firm's performance is relative to your competitors' performance:

We're the best We're the worst

Sales

Sales growth

Revenue

Growth of revenue

Profit

Growth of profit

Profitability (profit/revenue)

Return on assets (profit/assets)

$\begin{array}{lllllll}7 & 6 & 5 & 4 & 3 & 2 & 1\end{array}$

Solvency (Cash flow)

$\begin{array}{lllllll}7 & 6 & 5 & 4 & 3 & 2 & 1\end{array}$

$\begin{array}{lllllll}7 & 6 & 5 & 4 & 3 & 2 & 1\end{array}$

Ability to finance business growth with own funds

Firm's performance in general 
$\square$ Information technology is a cost, which must be controlled

14. What kind of vision about IT (usage) you or your firm has: (mark one)

$\square$ Strong and general vision: "We will be leader in our industry concerning IT usage".

$\square$ Technical vision: "We will implement modern communication network".

$\square$ Functional vision: "We will exchange the data with our suppliers by EDI".

$\square$ There is no vision about IT usage within our firm.

\section{How would you describe your firm's use of IT? (Mark one)}

$\square$ Industry leader $\square$ close follower $\square$ middle of the pack $\square$ somewhat behind

$\square$ laggard

16. Which one the best describes the role of IT in your firm? (Mark one)

$\square$ Integral role: (IT is integral part of the to strategy...)

$\square$ Evolving role: (IT supports strategy...)

Traditional role (IT supports operations....)

17. Your role in a firm (mark one or more):

$\square$ owner $\quad \square$ CEO $\quad \square$ manager $\quad \square$ employee $\square$ other:

Thank You for Your Participation 